\title{
FLY SIZE, EMERGENCE TIME AND STERNOPLEURAL CHAETA NUMBER IN DROSOPHILA
}

\author{
P. A. PARSONS \\ Deportment of Genetics, Milton Road, Cambridge
}

\section{INTRODUCTION}

Received 25.iv.61

IN the literature, there are observations in Drosophila melanogaster on the effect of environment on chaeta number. For example, Plunkett (I926) studied various genes affecting chaeta number, and showed that under conditions of increased competition, chaeta number was reduced. Similarly, as the temperature at which flies were grown was increased from $14^{\circ} \mathrm{C}$. to $30^{\circ} \mathrm{C}$., a general decrease in chaeta number occurred. He found no effect in his wild-type stock, but, as his initial experiments were done on a small number of chaetæ on each side of the fly, this is not surprising. More recently, data on sternopleural chaeta number have been collected at $20^{\circ} \mathrm{C}$., $25^{\circ} \mathrm{C}$., $30^{\circ} \mathrm{C}$. and a fluctuating temperature running smoothly from $30^{\circ} \mathrm{C}$. at midday to $20^{\circ} \mathrm{C}$. at midnight, and back to $30^{\circ} \mathrm{C}$. at midday (Thoday, 1958, quoting Beardmore) for the $F_{1}$ and subsequent generations from Oregon and Samarkand inbred lines. At $20^{\circ} \mathrm{C}$, , chaeta number was higher than at $25^{\circ} \mathrm{C}$., which in turn was higher than at $30^{\circ} \mathrm{C}$. The fluctuating temperature $\left(20 / 30^{\circ} \mathrm{C}\right.$.) gave about the same number of chaetæ as at $25^{\circ} \mathrm{C}$., as might be expected. After the flies were placed in their new environment, further changes occurred in subsequent generations. At $20^{\circ} \mathrm{C}$., chaeta number increased further, and at $30^{\circ} \mathrm{C}$. decreased further. This progressive change from generation to generation was taken to indicate that chaeta number is a character of adaptive significance. Similarly, sternopleural chaeta asymmetry decreased over the generations in the $30^{\circ} \mathrm{C}$. and $20 / 30^{\circ} \mathrm{C}$. environments, this suggesting that sterno-pleural symmetry is of adaptive significance.

Further evidence that sterno-pleural chaeta number is of adaptive significance is presented by Mather (1953), Tebb and Thoday (1954), Thoday (1955) and Beardmore (I960), and in other publications.

It seems, therefore, reasonable to report some results for flies grown at two levels of competition on various concentrations of the tyrosinase inhibitor phenyl-thio-carbamide (P.T.C.) at $25^{\circ}$ C. P.T.C. was shown by Parsons and Kroman (1960) to reduce the size of flies, and appeared to have no other morphological effect. An additional smaller experiment will be reported where flies grown at $30^{\circ} \mathrm{C}$. are compared with those grown at $25^{\circ} \mathrm{C}$. Thus it is possible to study relations between fly weight, which is a measure of fly size, and sterno-pleural chaeta number by growing flies on increasing concentrations of P.T.C. and at 
different temperatures. That there is probably some relation between fly weight and chaeta number is indicated by Reeve and Robertson's (1954) results on sternite chaeta number where they found that the male fly had fewer chaetæ than the female, and the reduction seemed to be related to the surface area of the fly, which is of course related to fly weight. This sex difference applies to sternopleural chaetæ also (Mather, 1953). Reeve and Robertson (1954) also found a correlation between fly size, as measured by thorax length, and chaeta number for flies grown under variable culture conditions. Mann (1923) found that flies carrying the gene sternopleural that developed slowly had fewer chaetæ than those developing more rapidly, and that the reduction in chaeta number was related to fly size. Preliminary results showing a correlation between chaeta number, surface area, and fly weight for various genotypes under different environmental conditions have been recently reported (Gibson, Parsons and Spickett, $196 \mathrm{I})$.

\section{METHOD}

Various numbers of replicates in $4^{\prime \prime}$ vials were set up for the three genotypes, Oregon- $\mathrm{R}(++)$, ebony" $\left(e^{\prime \prime} e^{\prime \prime}\right)$, and Oregon $\times$ ebony heterozygotes $\left(e^{\prime \prime}+\right)$ at 2 levels of competition, namely 25 and roo newly-hatched larvæ per vial on a series of concentrations of P.T.C. at $25^{\circ}$ C. For brevity, we shall refer to these 2 levels of competition as low and high levels. At high concentrations of P.T.C., the number of replicates was increased, in an attempt to obtain adequate data for meaningful results, since fewer flies were expected to emerge. The adults were scored daily as they emerged for fly weight and sternopleural chaeta number. A torsion balance accurate to $0.02 \mathrm{mgm}$. was used to measure fly weight.

A second smaller experiment was set up at $25^{\circ} \mathrm{C}$. and $30^{\circ} \mathrm{C}$. using the Oregon stock on a few levels of P.T.C., to obtain information on the effect of temperature on fly weight and chaeta number. In this experiment the high level of competition had I 50 larvæ per replicate, and the low level 25 larvæ per replicate.

\section{FLY WEIGHT AND P.T.C. CONCENTRATION}

In fig. I graphs of mean fly weight are given for each sex and each level of competition, for the 3 genotypes,$++ e^{\prime \prime}+$, and $e^{\prime \prime} e^{\prime \prime}$ on various concentrations of P.T.G. The points on these graphs have necessarily different accuracies, depending on the number of flies classified. However, they are adequate to show any trends. A few points at the highest concentrations are omitted since very few flies emerged, and would confuse any trends. All the points plotted are means from 5 or more flies.

These graphs show clearly that (I) females weighed more than males at a given level of competition on a given concentration of P.T.C., (2) flies grown at the high level of competition weighed less than those grown at the low level for a given sex on a given concentration of P.T.C., and (3) fly weight decreased as P.T.C. concentration was increased. The greatest decrease in fly weight occurred on low concentrations of P.T.G. For $e^{\prime \prime} e^{\prime \prime}$, most of the decrease occurred between the control and 0.01 per cent. P.T.C. At 0.05 per cent. P.T.C., no $e^{\prime \prime} e^{\prime \prime}$ flies survived as found by Parsons and Kroman (1960). 


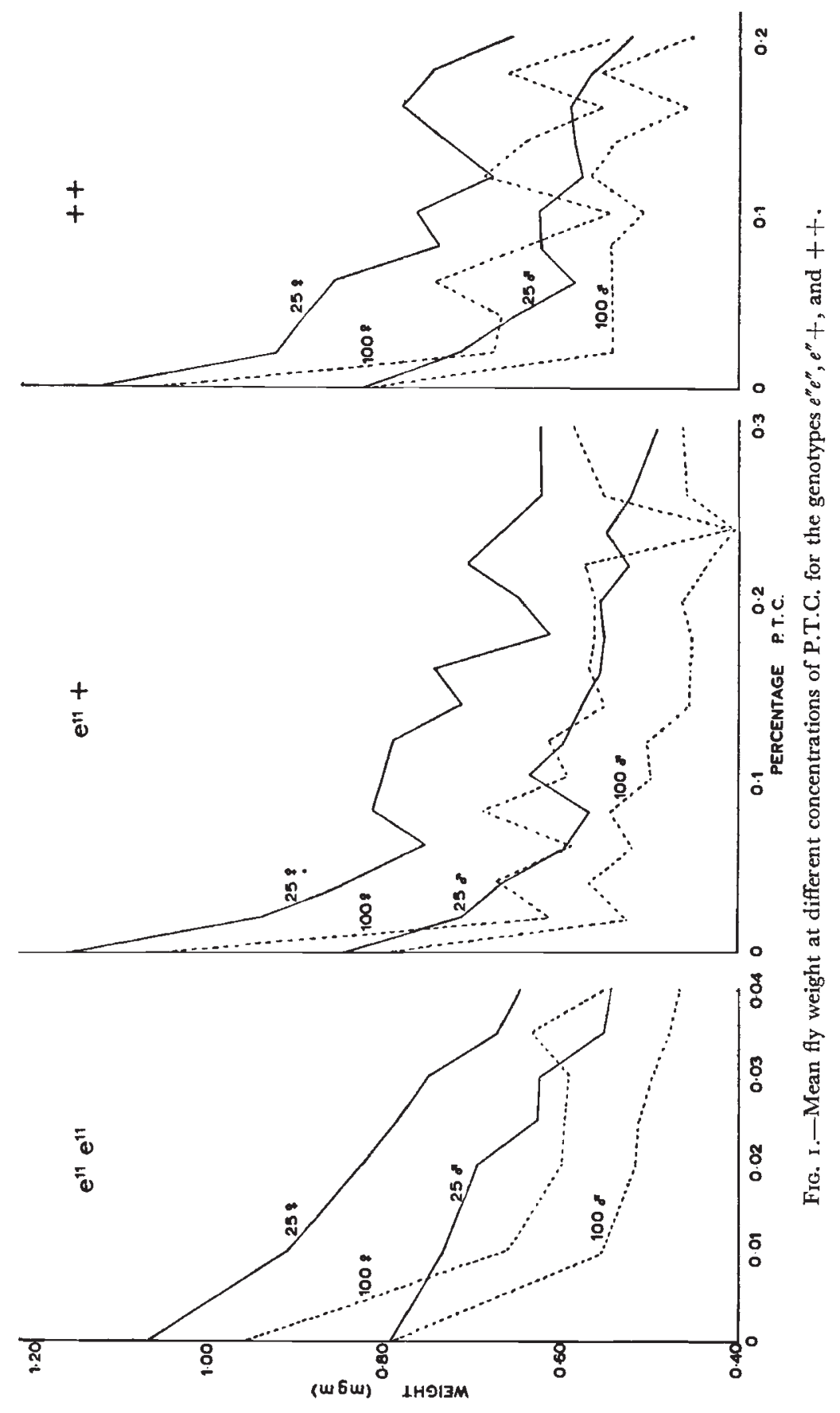


For $e^{\prime \prime}+$ and ++ , most of the decrease occurred between the control and 0.04 per cent. P.T.C. In this case, the lethal concentration was usually somewhat greater than 0.30 per cent. P.T.C. There was, however, a general tendency for fly weight to be slowly reduced at the higher concentrations of P.T.C. for all genotypes.

Coefficients of variation of fly weight were computed for some of the lower concentrations of P.T.C. (table I). To avoid confusion, coefficients of variation are not given for P.T.C. concentrations where some, or all, of the entries in the table would be based on less than 30 flies.

TABLE I

Fly weight and chaeta number variability

\begin{tabular}{|c|c|c|c|c|c|c|c|c|c|c|c|c|}
\hline \multirow{2}{*}{$\begin{array}{l}\text { Larvæ per } \\
\text { replicate }\end{array}$} & \multicolumn{4}{|c|}{$\begin{array}{l}\text { Fly weight } \\
\text { coefficient of } \\
\text { variation }\end{array}$} & \multicolumn{4}{|c|}{$\begin{array}{l}\text { Chaeta no. } \\
\text { coefficient of } \\
\text { variation }\end{array}$} & \multicolumn{4}{|c|}{$\begin{array}{l}\text { Chaeta no. } \\
\text { asymmetry } \\
\left(\begin{array}{l}\mathrm{A} \\
\overline{\mathrm{T}} \times 1000\end{array}\right)\end{array}$} \\
\hline & \multicolumn{2}{|c|}{25} & \multicolumn{2}{|c|}{100} & \multicolumn{2}{|c|}{25} & \multicolumn{2}{|c|}{100} & \multicolumn{2}{|c|}{25} & \multicolumn{2}{|c|}{100} \\
\hline$e^{\prime \prime} e^{\prime \prime}$ & o. & $\delta$ & $q$ & 0 & q & 3 & 우 & 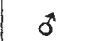 & 우 & $\sigma$ & 우 & \\
\hline Control & $0 \cdot 061$ & $0 \cdot 05^{8}$ & 0.061 & 0.069 & 0.067 & $0 \cdot 100$ & $0 \cdot 09^{2}$ & $0 \cdot 103$ & $5^{6}$ & $5^{8}$ & 53 & 70 \\
\hline $\begin{array}{l}0.01 \text { per cent. P.T.C. } \\
\text { 0.02 per cent. P.T.C. }\end{array}$ & $\begin{array}{l}0 \cdot 102 \\
0 \cdot 096\end{array}$ & $\begin{array}{l}0.077 \\
0.099\end{array}$ & $\begin{array}{l}0.081 \\
0 \cdot 167\end{array}$ & $\begin{array}{l}0 \cdot 120 \\
0 \cdot 136\end{array}$ & $\begin{array}{l}0.084 \\
0 \cdot 110\end{array}$ & $\begin{array}{l}0.082 \\
0.090\end{array}$ & $\begin{array}{l}0 \cdot 104 \\
0 \cdot 101\end{array}$ & $\begin{array}{l}0 \cdot 107 \\
0 \cdot 083\end{array}$ & $\begin{array}{l}57 \\
68\end{array}$ & $\begin{array}{l}51 \\
56\end{array}$ & $\begin{array}{l}65 \\
55\end{array}$ & $\begin{array}{l}35 \\
61\end{array}$ \\
\hline & & & & & & & & & & & & \\
\hline Control & $0.08_{5}$ & 0.078 & 0.078 & 0.071 & 0.084 & 0.088 & $0 \cdot 095$ & $0 \cdot 101$ & 54 & 60 & $5^{6}$ & $5^{8}$ \\
\hline P.T.C. & 0.113 & 0.083 & 0.110 & 0.114 & 0.081 & & $0 \cdot 073$ & 0.097 & $5^{6}$ & 54 & 45 & 9 \\
\hline 0.04 per cent. P.T.C. & $0 \cdot 147$ & O.II0 & $0 \cdot 15^{8}$ & $0 \cdot 134$ & 0.094 & 0.092 & $0.09^{1}$ & 0.114 & 63 & 53 & 57 & 59 \\
\hline 0.08 per cent. P.T.C. & 0.123 & 0.170 & 0.173 & $0 \cdot 1$ & 0.081 & 0.088 & $0 \cdot 097$ & 0.087 & 59 & 46 & 42 & 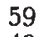 \\
\hline O.10 per cent. P.T.C. & $0 \cdot 164$ & $0 \cdot 134$ & $0 \cdot 176$ & $0 \cdot 206$ & 0.070 & & & $0 \cdot$ & 47 & 49 & 64 & 49 \\
\hline cent. P.T.C. & 0.234 & 0.204 & $0 \cdot 200$ & 0.220 & 0.077 & $0 \cdot 0$ & 0.086 & 0.087 & $5^{2}$ & 49 & $5^{1}$ & 55 \\
\hline 0.16 per cent. P.T.C. & 0.195 & 0.216 & 0.178 & 0.206 & 0.094 & 0.089 & $0 \cdot 103$ & $0 . \operatorname{III}$ & 47 & $5^{6}$ & $5^{\circ}$ & 55 \\
\hline++ & & & & & & & $\mid 0.088$ & 0.088 & $6 \mathrm{I}$ & 50 & 62 & \\
\hline $\begin{array}{l}\text { CONTROL } \\
0.02 \text { per cent. P.T.C. }\end{array}$ & $\begin{array}{l}0 \cdot 075 \\
0 \cdot 127\end{array}$ & $\begin{array}{l}0.089 \\
0.091\end{array}$ & $\begin{array}{l}0.081 \\
0.144\end{array}$ & $\begin{array}{l}0.000 \\
0.15^{2}\end{array}$ & $\begin{array}{l}0.102 \\
0.097\end{array}$ & $\begin{array}{l}0.070 \\
0.079\end{array}$ & $\begin{array}{l}-1 \\
0.000 \\
0.091\end{array}$ & 0.092 & 46 & 39 & 57 & $\begin{array}{l}39 \\
50\end{array}$ \\
\hline 0.04 per cent. P.T.C. & $0 \cdot 116$ & 0.103 & $0 \cdot 202$ & $0 \cdot 169$ & 0.097 & 0.088 & 0.087 & 0.079 & 60 & 65 & $5^{2}$ & 53 \\
\hline
\end{tabular}

In all cases, coefficients of variation increased with P.T.C. concentration. Flies differed in size between sexes (fig. I), but for a given treatment the coefficients of variation differed very little, so suggesting that the coefficient of variation assesses variability tolerably well, and is independent of the mean.

There was little difference in variability due to the levels of competition. Assuming that each coefficient of variation is equally accurate, which for $n>30$ is a fair approximation, an analysis of variance of the coefficients of variation can be done for each genotype to test possible effects of sex, competition and P.T.C. concentration. Multiplying the coefficients of variation by ıoo for convenience, we get the analyses of variance of the coefficients of variation as presented in table 2. For all genotypes, variation in P.T.C. concentration 
is significant, and for the homozygotes, there is a suggestion of a competition effect, such that at the high level of competition, the coefficients of variation are slightly higher than at the low level.

TABLE 2

Analyses of variance of the coefficients of variation of fly weight presented in table $I$

\begin{tabular}{|c|c|c|c|c|c|c|c|}
\hline & & & & & d.f. & M.S. & P. \\
\hline \multicolumn{8}{|l|}{$e^{\prime \prime} e^{\prime \prime}$} \\
\hline Levels of P.T.C. & . & & & . & 2 & $3878 \cdot 5^{8}$ & $<0.05$ \\
\hline Competition . & . & & . & . & I & $1656 \cdot 75$ & $<0 \cdot 20$ \\
\hline $\operatorname{Sex}$ & . & & & . & I & $6 \cdot 75$ & $>0.20$ \\
\hline Competition $\times$ Sex & . & & & . & I & $140 \cdot 08$ & $>0.20$ \\
\hline Error & . & & & 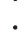 & 6 & $476 \cdot 36$ & $\ldots$ \\
\hline \multicolumn{8}{|l|}{$e^{\prime \prime}+$} \\
\hline Levels of P.T.C. & . & & & . & 6 & $9543 \cdot 29$ & $<0.001$ \\
\hline Competition . & 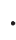 & & & . & I & 488.89 & $>0.20$ \\
\hline$\therefore \quad$. & 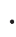 & & & . & I & $54 \cdot 32$ & $>0.20$ \\
\hline Competition $\times$ Sex & 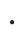 & & & . & $\mathrm{I}$ & $308 \cdot 89$ & $>0.20$ \\
\hline Error $\cdot$ & · & & & - & 18 & $387 \cdot 29$ & $\cdots$ \\
\hline \multicolumn{8}{|l|}{++} \\
\hline Levels of P.T.C. & . & & & - & 2 & $\begin{array}{l}4655^{\circ} 08 \\
4294 \cdot 08\end{array}$ & $\begin{array}{l}<0.05 \\
<0.05\end{array}$ \\
\hline $\begin{array}{l}\text { Competition : } \\
\text { Sex }\end{array}$ & : & & . & · & $\begin{array}{l}1 \\
1\end{array}$ & $\begin{array}{r}4294 \cdot 08 \\
310 \cdot 08\end{array}$ & $\begin{array}{l}<0 \cdot 05 \\
>0 \cdot 20\end{array}$ \\
\hline Competition $\times$ Sex & . & & & . & I & $6 \cdot 75$ & $>0 \cdot 20$ \\
\hline Error . & . & & & . & 6 & $682 \cdot 64$ & $\ldots$ \\
\hline
\end{tabular}

If, as before, we regard the coefficients of variation as equally accurate, i.e. contributing equal information in the statistical sense, then we can add the 4 coefficients for each level of P.T.G., and do a regression analysis of these summed coefficients on P.T.C. concentration for each genotype. The regression coefficients obtained, with

TABLE 3

Significance of regression of coefficients of variation of fly weight on P.T.C. concentration

\begin{tabular}{|c|c|c|c|}
\hline & Genotype & $\begin{array}{l}\text { Regression } \\
\text { coefficient }\end{array}$ & Probability \\
\hline$e^{\prime \prime} e^{\prime \prime}$ & . & $\mathrm{I} \cdot 25$ & $<0.05$ \\
\hline$e^{\prime \prime}+$ & . & 0.31 & $<0.001$ \\
\hline$+t$ & . . & $\mathrm{I} \cdot 3^{2}$ & $<0 \cdot 20$ \\
\hline
\end{tabular}

levels of significance, are given in table 3 , and indicate that as P.T.C. concentration was increased, the coefficients of variation increase in parallel.

All cultures were classified daily until emergence had finished to obtain total emergence figures. To compare these, percentage emergence is given in table 4 for the 3 genotypes. This is the easiest method 
of comparison, since variable numbers of replicates were used during the course of the experiment. As might be expected, percentage emergence fell as P.T.C. concentration was increased. There was little difference in levels of competition. Parsons and Kroman (1960) found that more flies emerged at the high level than at the low level on 0.04 per cent. P.T.C. This effect does not occur consistently in the results reported here, so the phenomenon, although statistically significant in Parsons' and Kroman's (1960) data, apparently depends

TABLE 4

Percentage emergence

\begin{tabular}{|c|c|c|}
\hline \multirow{2}{*}{$\begin{array}{l}\text { Larvæ per } \\
\text { replicate }\end{array}$} & \multicolumn{2}{|c|}{$e^{\prime \prime} e^{\prime \prime}$} \\
\hline & 25 & 100 \\
\hline $\begin{array}{l}\text { CONTROL } \\
\text { O.01 per cent. P.T.C. } \\
\text { 0.02 per cent. P.T.C. } \\
\text { 0.03 per cent. P.T.C. } \\
\text { 0.04 per cent. P.T.C. }\end{array}$ & $\begin{array}{l}57 \\
72 \cdot 5 \\
61 \cdot 5 \\
9 \cdot 33 \\
6\end{array}$ & $\begin{array}{r}50 \cdot 5 \\
47 \cdot 5 \\
46 \cdot 5 \\
28 \cdot 67 \\
3 \cdot 75\end{array}$ \\
\hline
\end{tabular}

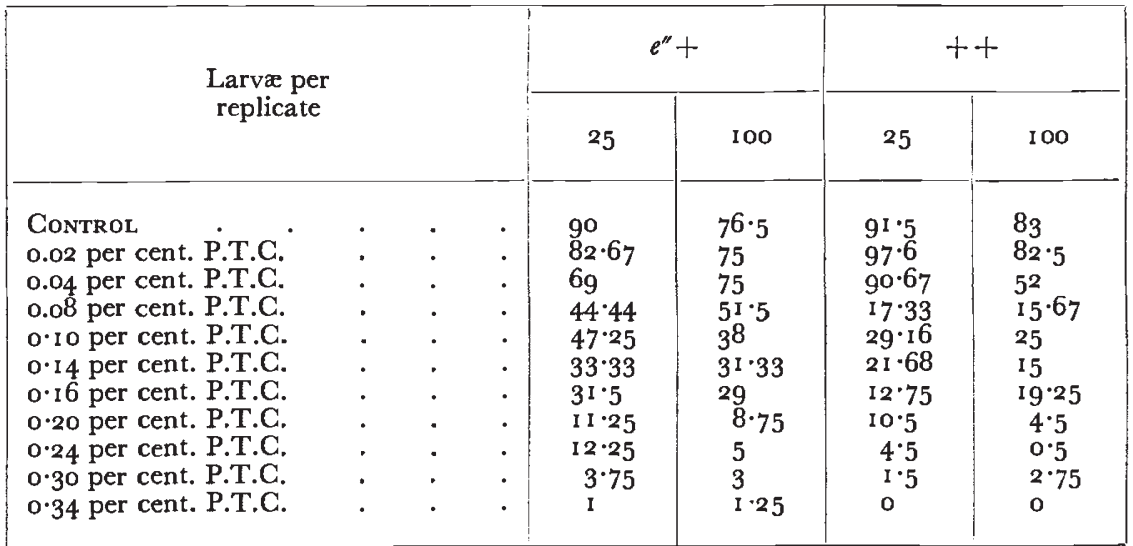

considerably on the precise culture conditions. At lower concentrations $(0.02$ and 0.04 per cent. P.T.C.), there was no great difference in emergence between ++ and $e^{\prime \prime}+$, but at concentrations above 0.08 per cent. P.T.G., $e^{\prime \prime}+$ became heterotic as found by Parsons and Kroman (I960).

In table 5, means and coefficients of variation of emergence time (the time taken for newly hatched larvæ to emerge as adults) are given. Both increased as P.T.C. concentration increased, and in all cases they were larger at the high level of competition than at the low level. Parsons and Kroman (1960) reported similar results. Hence, correlated with decreasing fly weight and increasing variability of fly weight is a prolongation of emergence time. 


\section{CHAETA NUMBER AND P.T.C. CONCENTRATION}

In fig. 2, chaeta number is plotted against P.T.C. concentration for each sex, level of competition and genotype. The graphs show (I) females had more chaetæ than males for a given level of competition and P.T.C. concentration, (2) flies at the high level of competition had fewer chaetæ than those grown at the low level for a given sex on a given concentration of P.T.C., and (3) chaeta number decreased as P.T.C. concentration was increased. The greatest decrease of chaeta number occurred on low concentrations of P.T.C.

TABLE 5

Means and coefficients of variation of emergence time

\begin{tabular}{|c|c|c|c|c|c|c|c|}
\hline \multirow{2}{*}{$\begin{array}{l}\text { Larvæ per } \\
\text { replicate }\end{array}$} & & & & \multicolumn{2}{|c|}{$\begin{array}{c}\text { Emergence time } \\
\text { (days) }\end{array}$} & \multicolumn{2}{|c|}{$\begin{array}{l}\text { Coefficient of variation } \\
\text { of emergence time }\end{array}$} \\
\hline & & & & 25 & 100 & 25 & 100 \\
\hline \multicolumn{8}{|l|}{$e^{\prime \prime}$} \\
\hline Control & . & & & $7 \cdot 63$ & $8 \cdot 01$ & 0.066 & 0.093 \\
\hline o.or per cent. P.T.C. & & & & $7 \cdot 75$ & $8 \cdot 05$ & 0.067 & 0.109 \\
\hline 0.02 per cent. P.T.C. & . & . & . & $8 \cdot 64$ & $10 \cdot 23$ & $0.06 \mathrm{r}$ & 0.109 \\
\hline \multicolumn{8}{|l|}{$e^{\prime \prime}+$} \\
\hline Control & . & . & . & $7 \cdot 02$ & $7 \cdot 42$ & 0.018 & 0.067 \\
\hline 0.02 per cent. P.T.C. & . & . & . & $7 \cdot 06$ & $7 \cdot 69$ & 0.039 & 0.077 \\
\hline 0.04 per cent. P.T.C. & . & . & . & $7 \cdot 21$ & $8 \cdot 17$ & 0.079 & 0.110 \\
\hline 0.08 per cent. P.T.C. & . & . & . & $8 \cdot 91$ & $9 \cdot 79$ & 0.132 & 0.124 \\
\hline o. Io per cent. P.T.C. & . & . & . & $8 \cdot 47$ & 10.29 & $0 \cdot 108$ & 0.147 \\
\hline O.14 per cent. P.T.C. & . & . & . & $9 \cdot 45$ & $11 \cdot 35$ & 0.083 & $0 \cdot 198$ \\
\hline o.16 per cent. P.T.C. & . & . & . & $9 \cdot 5^{6}$ & $11 \cdot 67$ & 0.084 & 0.199 \\
\hline++ & & & & & & & \\
\hline CONTROL . & . & . & . & & & & $0 \cdot 086$ \\
\hline 0.02 per cent. P.T.C. & . & . & . & $7 \cdot 24$ & 9.02 & 0.075 & 0.107 \\
\hline 0.04 per cent. P.T.C. & . & & . & $7 \cdot 9^{8}$ & $10 \cdot 57$ & 0.097 & $0.13^{6}$ \\
\hline
\end{tabular}

Fly weight and chaeta number therefore react similarly to the various stresses. This suggests that the two variables are correlated. This possibility is discussed in section 5 .

In table I, coefficients of variation of chaeta number are given, but unlike fly weight no trend is obvious. Furthermore, the analyses of variance of the coefficients of variation showed no trends.

We can also study asymmetry of chaeta number between the 2 sides of the fly. Asymmetry has been measured as the summed absolute differences $\mathrm{A}$ between the 2 sides of a set of flies, divided by their total chaeta number $\mathrm{T}$ by Thoday (1955, I958) and Beardmore (I960). This measure of asymmetry has been recently criticised by Reeve (I96o), who maintains that there are always 3 macro-chaetæ on each side of the fly, hence we should divide by the total chaeta number minus 6. However, it is not possible in all flies to find 3 macro-chaetæ; 


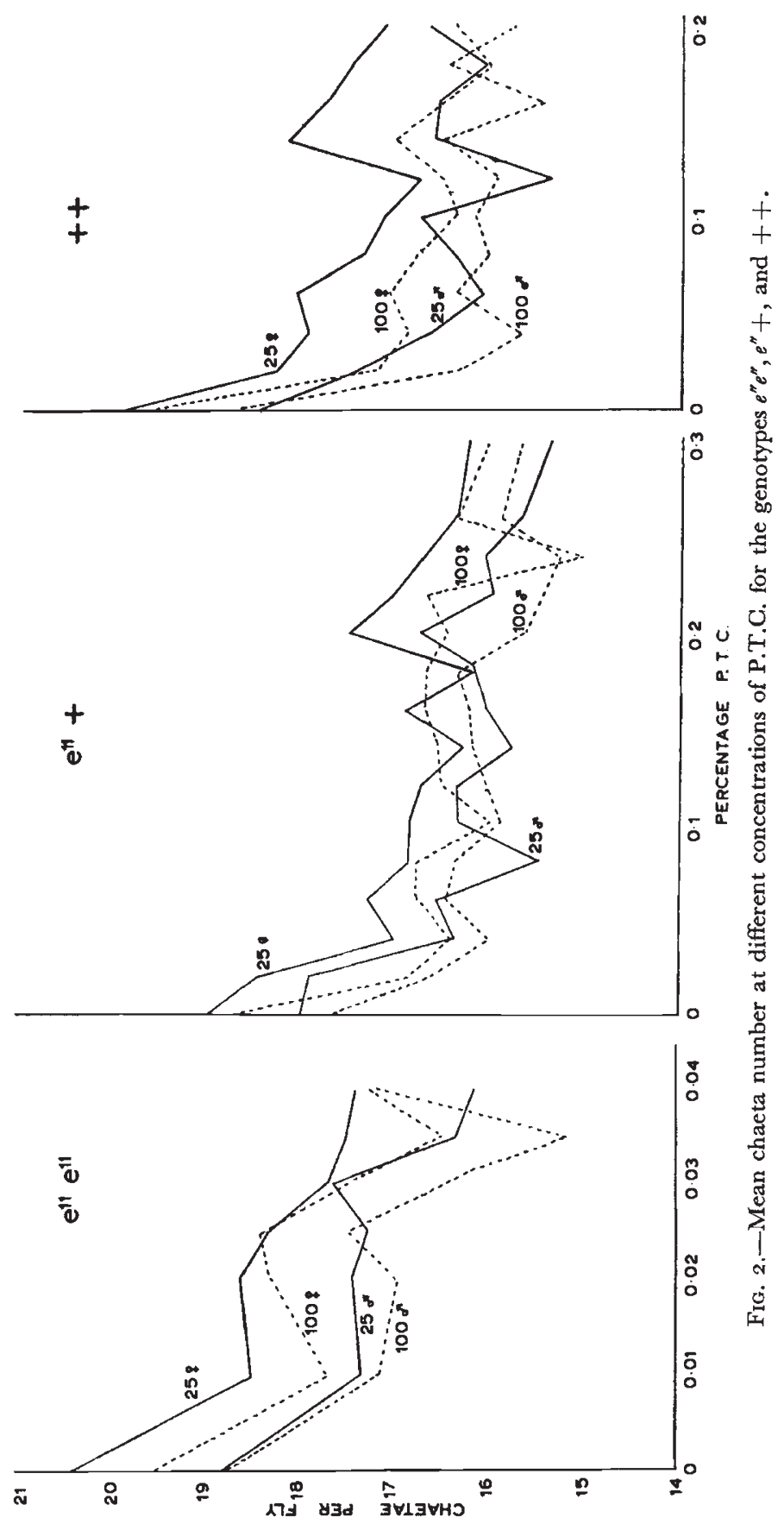


in small flies there are often 2, and sometimes it is hard to distinguish macro- and micro-chaetæ. For this reason, it does not appear justifiable to change from the measure $\frac{\mathrm{A}}{\mathrm{T}}$ postulated above. Such values were estimated, and for convenience multiplied by rooo (table I). If all asymmetry values are assumed to be equally informative, analyses of variance can be done on them. No significant effect of genotype, sex, competition, or P.T.C. concentration was apparent on asymmetry. Thus the stress of P.T.C. which increased fly weight variability, did not increase chaeta number variability or asymmetry, even though there appears to be a correlation between chaeta number and fly weight. This conclusion is perhaps a little surprising, but may be resolvable if we can determine more precisely when chaeta numbers and positions are determined in the developing fly, and the variability of fly size at this stage.

\section{CHAETA NUMBER AND FLY WEIGHT}

As a preliminary, mean chaeta number was plotted against fly weight for each sex and level of competition for each concentration of P.T.C., provided that the mean was based on more than 5 observations. In fig. 3, the resultant scatter diagrams are given for the 3 genotypes. It is obvious that chaeta number and fly weight are correlated as suggested earlier from figs. I and 2. Fig. 3 shows that this correlation appears to be linear, thus chaeta number is proportional to fly weight.

To confirm this, a linear regression analysis of chaeta number on fly weight must be done. Such regression coefficients, which are all highly significant $(\mathrm{P}<0 \cdot 00 \mathrm{I})$, are given for various contrasts in table 6 . Comparing the total data for the 3 genotypes, we see that the $e^{\prime \prime}+$ coefficient is less than the ++ and $e^{\prime \prime} e^{\prime \prime}$ coefficients. In fact, a test of significance (table 6) reveals that this difference is significant. Thus chaeta number decreased relatively less rapidly with decreasing weight in the heterozygotes than in the homozygotes. We have seen that the heterozygotes survive better at higher concentrations of P.T.C. (table 4). If sterno-pleural chaeta number is of adaptive value, as is certainly the case, then it is reasonable that there is a relationship between greater survival ability of $e^{\prime \prime}+$, and a smaller rate of decrease of chaeta number with decreasing fly weight, than occurred in the homozygotes. The heterozygotes may therefore have somewhat better developmental stability than the homozygotes.

We can also test for the effects of sex and competition within each genotype. If all the regression coefficients given in table $6(I)(b)$ are assumed to be equally accurate, i.e. contribute equal information, a simple $t$ test will test the difference between sexes and levels of competition. The assumption of equal information is reasonable, since the number of degrees of freedom on which the coefficients in 

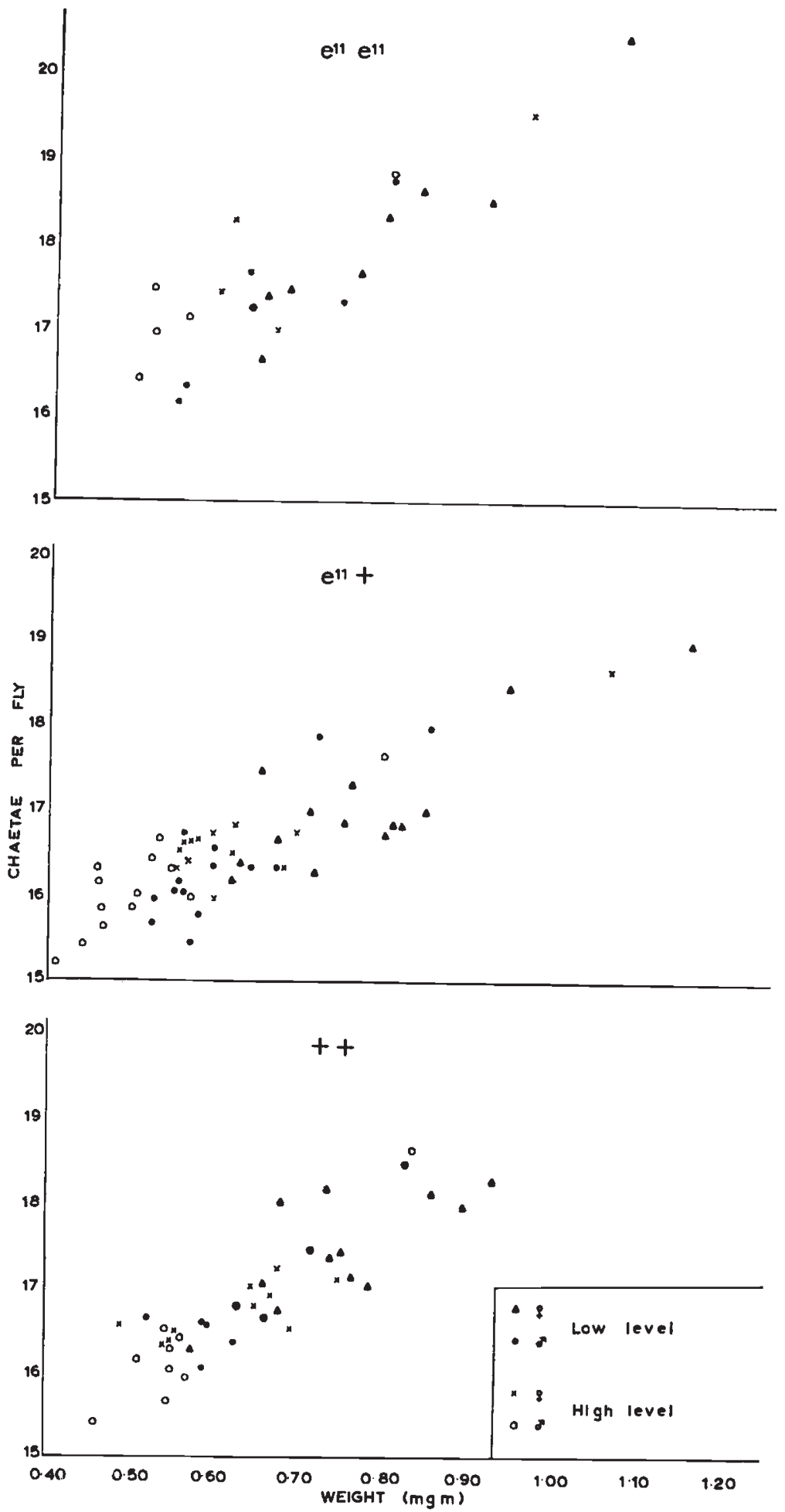

FIG. 3.-The relation between fly weight and chaeta number for the genotypes $e^{\prime \prime} e$, $e^{\prime \prime}+$ and ++ . 
table $6(I)(b)$ are based do not vary much within genotypes. Mean values of the regression coefficients are given in table $6(I)(c)$ for sexes and levels of competition.

The mean values show that for all genotypes and levels of competition, the male regression lines are steeper than the female regression lines, and these differences are significant (table 6 (2)). An interpretation of this sex difference is a little difficult to find, but it may be a result of variability of female flies induced by egg formation.

TABLE 6

(I) Regression coefficients of chaeta number on fly weight (mgm.)

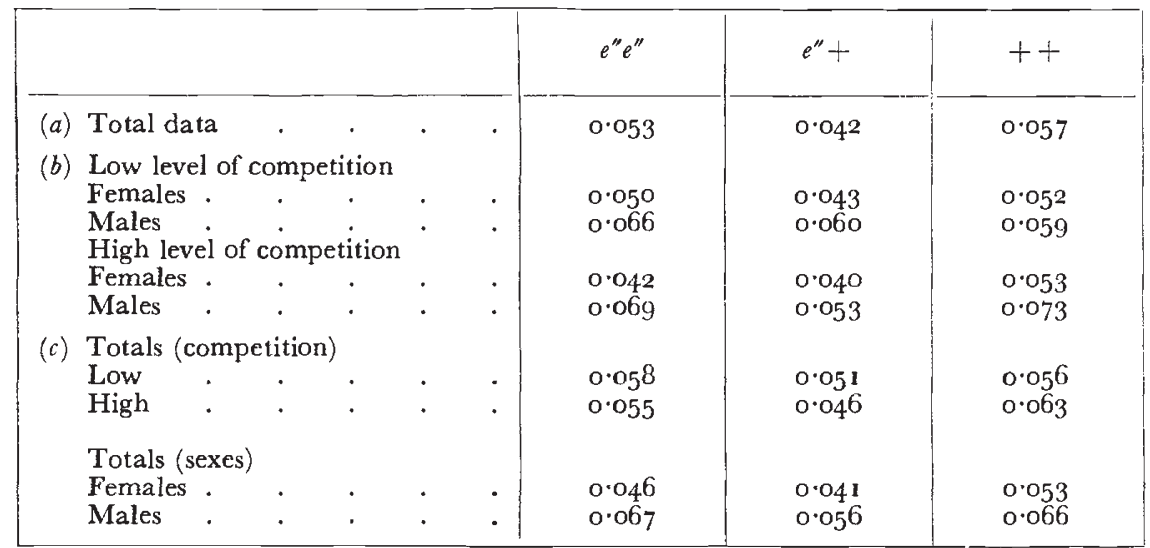

All regression coefficients are significantly $>0(\mathrm{P}<<0.001)$.

(2) $\mathrm{t}$ tests on the regression coefficients in table $6(\mathrm{I}) \mathrm{c}$

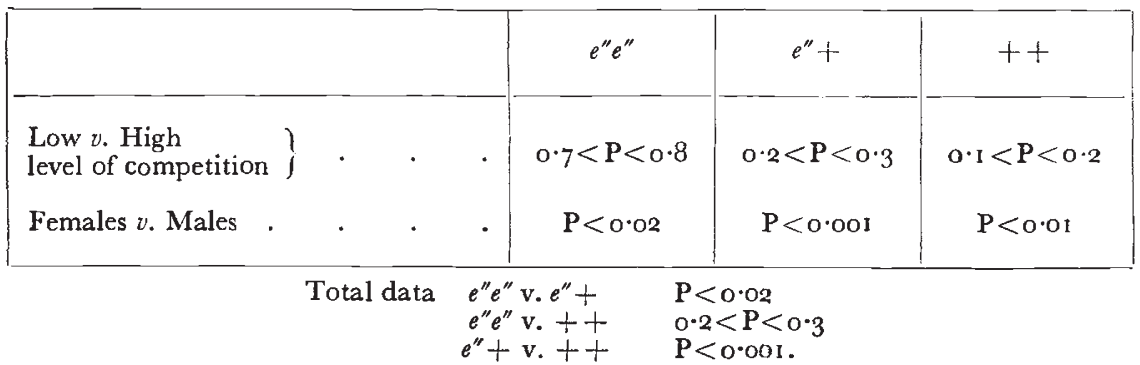

The level of competition has no effect on the slope of the regression lines. Presumably, as shown in figs. I and 2, the high level of competition leads to smaller flies, with proportionately fewer chaetæ, but the rate of decrease of fly weight with chaeta number does not vary between levels of competition. It appears therefore that a competition effect found by Gibson (unpublished) is related to fly size. He found that flies grown in 4-inch vials had fewer sterno-pleural chaetæ than those grown in half-pint milk bottles, presumably because competition is more intense in vials so giving smaller flies. Furthermore, Rasmuson (1952) found that flies had fewer abdominal and sterno-pleural chaetæ at a high level of competition. 


\section{FLY WEIGHT, TEMPERATURE AND CHAETA NUMBER}

Firstly, we will consider the effect of temperature on the control medium (table 7). The following conclusions are apparent; (I) fly weight was reduced by increased temperature, (2) chaeta number was reduced by increased temperature as found in previous experiments (see Rasmuson, 1952, and Thoday, 1958), (3) fly weight and chaeta number were lower at the high level of competition at a given temperature than at the low level, (4) at the low level of competition, coefficients of variation of fly weight did not differ appreciably between temperatures, but at the high level, the variability of fly weight was

TABLE 7

Fly weight and chaeta numbers at $25^{\circ} \mathrm{C}$. and $30^{\circ} \mathrm{C}$.

\begin{tabular}{|c|c|c|c|c|c|c|c|c|c|c|}
\hline \multirow{6}{*}{$\begin{array}{l}25^{\circ} \mathrm{C} . \\
\text { Control (Low) }{ }^{*} \\
\text { Control (High) } \dagger \\
0.02 \text { per cent. P.T.C. } \dagger \\
0.04 \text { per cent. P.T.C. } \dagger\end{array}$} & \multicolumn{2}{|c|}{$\begin{array}{c}\text { Fly weight } \\
(\mathrm{mgm} . \times \text { IOO })\end{array}$} & \multicolumn{2}{|c|}{$\begin{array}{l}\text { Fly weight } \\
\text { coefficient of } \\
\text { variation }\end{array}$} & \multicolumn{2}{|c|}{ Chaeta no. } & \multicolumn{2}{|c|}{$\begin{array}{l}\text { Chaeta no. } \\
\text { coefficient of } \\
\text { variation }\end{array}$} & \multicolumn{2}{|c|}{$\begin{array}{l}\text { Chaeta no. } \\
\text { asymmetry } \\
\left(\begin{array}{l}\mathrm{A} \\
\overline{\mathrm{T}}\end{array} \mathrm{1000}\right)\end{array}$} \\
\hline & q & $\sigma^{\prime}$ & 우 & 0 & $q$ & $\sigma^{3}$ & 우 & & 우 & $0^{*}$ \\
\hline & $\mid \begin{array}{lll}1 & 1 & 1 \\
\end{array}$ & $84 \cdot 98$ & 0.077 & 0.091 & 19.90 & $19 \cdot 16$ & $0 \cdot 075$ & $0 \cdot 086$ & 60 & 60 \\
\hline & $88 \cdot 38$ & $66 \cdot 55$ & O.III & 0.090 & 17.87 & $17 \cdot 17$ & 0.077 & 0.079 & $5 \mathrm{I}$ & 50 \\
\hline & $\begin{array}{l}60 \cdot 15 \\
54 \cdot 58\end{array}$ & $49 \cdot 73$ & $\begin{array}{l}0 \cdot 189 \\
0 \cdot 206\end{array}$ & 0.220 & $16 \cdot 89$ & $16 \cdot 25$ & 0.086 & $\begin{array}{l}0.083 \\
0.068\end{array}$ & 37 & 59 \\
\hline & 4 & 45 & & 0.190 & 1705 & 1004 & & 000 & 53 & \\
\hline $\begin{array}{l}30^{\circ} \mathrm{C} \text {. } \\
\text { ConTrol (Low) }\end{array}$ & $107 \cdot 6$ I & 80.07 & 0.074 & $0 \cdot 087$ & $18 \cdot 98$ & $18 \cdot 07$ & $0.09_{1}$ & 0.092 & 72 & \\
\hline Control $(\mathrm{High}) \dagger$ & $79 \cdot 97$ & $60 \cdot 62$ & 0.127 & 0.128 & $16.8_{2}$ & $16 \cdot 13$ & 0.093 & 0.091 & 69 & 55 \\
\hline 0.02 per cent. P. & $65 \cdot 8 \mathrm{I}$ & $54 \cdot 53$ & 0.206 & $0 \cdot 176$ & 16.86 & 15.49 & $0.09^{2}$ & 0.091 & 62 & $5^{6}$ \\
\hline 0.04 per cent. P.T.C. $\dagger$ & $5^{8 \cdot 44}$ & $49 \cdot 27$ & 0.224 & 0.188 & $16 \cdot 44$ & $15 \cdot 27$ & 0.092 & 0.078 & 68 & 48 \\
\hline
\end{tabular}

* Four replicates of 25 larva.

† One replicate of 150 larva.

greater at $30^{\circ} \mathrm{C}$. than at $25^{\circ} \mathrm{C}$., and (5) at $25^{\circ} \mathrm{C}$. the coefficients of variation of chaeta number were lower than at $30^{\circ} \mathrm{C}$.

Thus at $30^{\circ} \mathrm{C}$. the flies were smaller than at $25^{\circ} \mathrm{C}$., and correlated with this was a reduction in chaeta number. Variations in sternopleural chaeta number reported by other authors as due to temperature, and level of competition, therefore appear to depend at least partly on fly size. Preliminary results reported by Gibson, Parsons and Spickett (I96I) confirm this.

Fly weight variability appears little affected by temperature, which is in contrast with P.T.G., where even a very low concentration of P.T.C. was effective in increasing fly weight variability. The combination of high temperature and high competition increased variability somewhat, but not to the same extent as P.T.C. in the medium. A temperature of $30^{\circ} \mathrm{C}$. is a severe stress, for at $3 \mathrm{I}^{\circ} \mathrm{C}$. it is unlikely that more than a few flies would survive. Chaeta number variability was, however, considerably greater at $30^{\circ} \mathrm{C}$. than at $25^{\circ} \mathrm{C}$., whereas 
P.T.G. has been shown not to affect chaeta number variability appreciably.

Data were also collected at the high level of competition on P.T.C., for each temperature. Fig. 4 shows that as expected P.T.C. reduced fly weight, but less for the $30^{\circ} \mathrm{C}$. data than for the $25^{\circ} \mathrm{C}$. data. Such an interaction, if significant, is a little difficult to explain, but appears to be some sort of complex genotype $\times$ environment interaction. Chaeta number was reduced by the addition of P.T.C. as expected, but the trends are not so obvious as for fly weight.

As expected, fly weight variability was increased considerably as a result of P.T.G. treatment. To find out the major cause of the

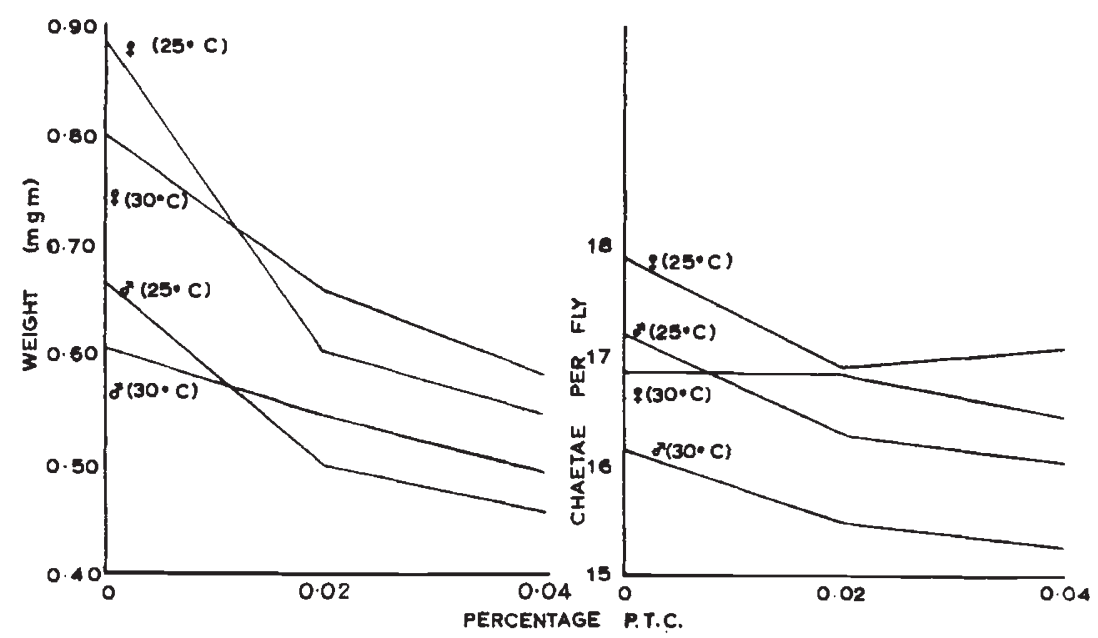

Fig. 4.-Mean fly weight and chaeta number at various concentrations of P.T.C. for the two temperatures $25^{\circ} \mathrm{C}$. and $30^{\circ} \mathrm{C}$.

variability of the coefficients of variation, we can do an analysis of variance to test the effect of the different treatments and sexes (table 8), assuming, as before, that the coefficients of variation are equally informative. The data collected on 0.04 per cent. P.T.C. were ignored, since very few flies emerged at $30^{\circ} \mathrm{C}$. The competition and P.T.C. component is significant, showing that the variability in these data differs with level of competition and P.T.C. treatment. Although, as pointed out, the data appear more variable at $30^{\circ} \mathrm{C}$. than $25^{\circ} \mathrm{C}$., this increase in variability is not significant in an analysis of variance.

A high level of competition with P.T.C. present increased emergence time and its variability (table 9) as expected from the results already presented (table 5). At $30^{\circ} \mathrm{C}$. emergence time was less than at $25^{\circ} \mathrm{C}$., especially on 0.02 per cent. P.T.C. Thus correlated with a smaller fly at $30^{\circ} \mathrm{C}$., and fewer chaetæ was a reduced development time.

Chaeta number variability was not affected by the presence of P.T.C., in agreement with previous results (table I). In table $8(b)$ an analysis of variance of the coefficients of variation confirms that at 
TABLE 8

Analyses of variance of the coefficients of variation of fyy weight and chaeta number, and of chaeta asymmetry (from data presented in table 7)

(a) Analysis of variance of the coefficients of variation of fly weight

\begin{tabular}{|c|c|c|c|c|c|c|}
\hline \multicolumn{7}{|c|}{ (a) Analysis of variance of the coefficients of variation of fly weight } \\
\hline $\begin{array}{l}\text { Competition and P.T.C. } \\
\text { Sex } \\
\text { Temperature : } \\
\text { Temperature } \times \text { Sex : } \\
\text { Error } .\end{array}$ & ' & $\begin{array}{l}\dot{ } \\
\dot{ } \\
\dot{ }\end{array}$ & $\dot{.}$ & $\begin{array}{l}2 \\
1 \\
1 \\
1 \\
6\end{array}$ & $\begin{array}{r}\text { M.S. } \\
14241 \cdot 59 \\
5 \cdot 33 \\
33 \cdot 33 \\
133 \cdot 33 \\
347 \cdot 58\end{array}$ & $\begin{array}{c}\quad P \\
P<0.00 r \\
P>0.20 \\
P>0.20 \\
P>0.20 \\
\quad \cdots\end{array}$ \\
\hline \multicolumn{7}{|c|}{ (b) Analysis of variance of the coefficients of variation of chaeta number } \\
\hline $\begin{array}{l}\text { Competition and P.T.C. } \\
\text { Sex } \\
\text { Temperature : } \\
\text { Temperature } \times \text { Sex : } \\
\text { Error } .\end{array}$ & : & : & $\dot{.}$ & $\begin{array}{l}2 \\
1 \\
1 \\
1 \\
6\end{array}$ & $\begin{array}{r}9 \cdot 33 \\
5 \cdot 33 \\
341 \cdot 33 \\
12 \cdot 00 \\
12 \cdot 89\end{array}$ & $\begin{array}{c}P>0.20 \\
P>0.20 \\
P<0.01 \\
P>0.20 \\
\cdots\end{array}$ \\
\hline \multicolumn{7}{|c|}{ (c) Analysis of variance of chaeta asymmetry (measured as $A / T \times I 000$ ) } \\
\hline $\begin{array}{l}\text { Competition and P.T.C. } \\
\text { Sex } \\
\text { Temperature : } \\
\text { Temperature } \times \text { Sex } \\
\text { Error } .\end{array}$ & . & : & $\dot{b} \dot{ }$ & $\begin{array}{l}2 \\
1 \\
1 \\
1 \\
6\end{array}$ & $\begin{array}{r}33 \cdot 08 \\
56 \cdot 33 \\
147 \cdot 00 \\
385 \cdot 33 \\
64 \cdot 97\end{array}$ & $\begin{array}{c}\mathrm{P}>0.20 \\
\mathrm{P}>0.20 \\
\mathrm{P}<0.20 \\
\mathrm{P}<0.10 \\
\quad \cdots\end{array}$ \\
\hline
\end{tabular}

TABLE 9

Emergence time in days and its variability at $25^{\circ} \mathrm{C}$. and $30^{\circ} \mathrm{C}$.

\begin{tabular}{|l|c|c|c|c|c|}
\hline & $\begin{array}{c}25^{\circ} \mathrm{C} . \\
\text { mean }\end{array}$ & $\begin{array}{c}\text { Coefficient } \\
\text { of variation }\end{array}$ & $\begin{array}{c}30^{\circ} \mathrm{C} . \\
\text { mean }\end{array}$ & $\begin{array}{c}\text { Coefficient } \\
\text { of variation }\end{array}$ & $\begin{array}{c}\text { Significance } \\
\text { of difference } \\
\text { between } \\
\text { means }\end{array}$ \\
\hline Control (low). & 7.20 & 0.059 & 6.86 & 0.056 & $\mathbf{P}<0.001$ \\
Control (high) & 9.07 & 0.098 & 8.77 & 0.074 & $\mathbf{P}<0.01$ \\
0.02 per cent. P.T.C. & 10.58 & 0.173 & 9.47 & 0.108 & $\mathbf{P}<0.001$ \\
\hline
\end{tabular}

$30^{\circ} \mathrm{C}$. chaeta number variability was greater than at $25^{\circ} \mathrm{C}$. At $30^{\circ} \mathrm{C}$. the mean coefficient of variation of chaeta number was 0.092 and at $25^{\circ} \mathrm{C}$. it was $0 \cdot 08 \mathrm{I}$.

Finally, chaeta asymmetry was calculated as $\frac{\mathrm{A}}{\mathrm{T}} \times$ I0oo. At $30^{\circ} \mathrm{C}$. the mean value of $\frac{\mathrm{A}}{\mathrm{T}} \times$ I00o $=59.8$, and at $25^{\circ} \mathrm{C}$. it came to $5^{2 \cdot 8}$, 
assuming all asymmetry values to be equally informative (omitting the data for 0.04 per cent. P.T.C.). The analysis of variance of the asymmetry values (table $8 b$ ) is suggestive of a temperature effect, but more data are needed to confirm this although greater asymmetry at $30^{\circ} \mathrm{C}$. agrees with Thoday's (1955 and $195^{8}$ ) results. There is a suggestion of a temperature $\times$ sex interaction, which if valid, is a little difficult to interpret.

Thus, at $30^{\circ} \mathrm{C}$., flies deteriorate in developmental homeostasis as a result of the environmental change; accidents of development being more frequent at this temperature. It was noted, too, that out of 315 flies classified at $30^{\circ} \mathrm{C}$., Io had crumpled or curled wings, whereas at $25^{\circ} \mathrm{C}$. out of $45 \mathrm{I}$ classified, none was affected. One fly at $30^{\circ} \mathrm{C}$. was exceptional in having 24 sterno-pleural chaetæ on the left side and 9 on the right side. This fly was so grossly abnormal that it was omitted from the main analysis. These abnormalities merely confirm that at $30^{\circ} \mathrm{C}$. developmental homeostasis breaks down fairly generally.

\section{DISCUSSION}

(i) Variability of fly weight and chaeta number

In this paper we are studying the effect of three environmental stresses, namely P.T.C., which is known to reduce fly size, temperature which is known to affect chaeta number, and competition. The results indicate a fairly direct correlation between fly size as measured by weight, and chaeta number for these three stresses.

The environmental stresses, P.T.C. and temperature, differ in nature. P.T.C. reduced fly weight and increased its variability. Emergence time was delayed by P.T.C., and its variability increased. P.T.C., however, had little effect on chaeta number variability and asymmetry. It therefore has little effect on the developmental stability of flies, and constitutes a stress affecting fly weight, but not the variability of the morphological structure of the fly.

Ebony larvæ die on lower concentrations of P.T.C. than wild-type larvæ (Kroman and Parsons, 1960), since the tyrosinase activity of ebony larvæ is lower (Ohnishi, I954). Correlated with this is an increase of the size of the nuclei of the corpus allatum portion of Weismann's ring in ebony larvæ (Wolsky and Kalicki, 1959). Perhaps the somewhat longer development time of ebony larvæ (table 5) is connected with some sort of variation in juvenile hormone synthesis from the larger, and presumably more polytenic, nuclei of ebony larvæ, and this leads, as suggested by Wolsky and Kalicki (1959) to an eventual inhibition of tyrosinase activity. P.T.C., by inhibiting tyrosinase, may have the effect of delaying pupation by a complex interaction with the juvenile, or related, hormones. It is unlikely that such a mechanism would also increase chaeta number variability and asymmetry appreciably, whereas it seems reasonable that fly weight and emergence time are much more susceptible to P.T.C., since these are the components of fitness more directly under stress. 
Temperature, however, increased chaeta number variability and asymmetry at $30^{\circ} \mathrm{C}$. because of poorer developmental stability of the morphological structure of the fly, whereas fly weight and emergence time variability were little affected. In this case, the component of fitness which is reacting most to the stress by increasing its variability is chaeta number. Furthermore, other abnormalities were common, such as crumpled and curled wings. Although fly weight was reduced slightly, this was obviously not affected critically, and presumably at temperatures a little above $30^{\circ} \mathrm{C}$., death would occur because of general poor homeostasis of the morphological structure of the fly.

P.T.C. specifically affects tyrosinase production and is therefore a much more "specific" environmental stress than temperature which probably affects many developmental pathways differentially so that various interactions would occur at different temperatures. Temperature is therefore a "general " environmental stress.

TABLE IO

A comparison of fies at $17^{\circ} \mathrm{C}$. and $25^{\circ} \mathrm{C}$. (I50 larva per replicate)

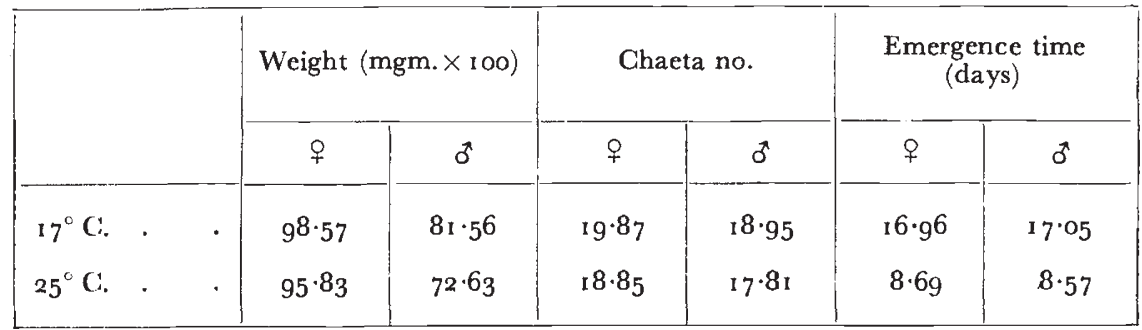

At $30^{\circ} \mathrm{C}$. flies were smaller with fewer chaetæ and developed more rapidly than at $25^{\circ} \mathrm{C}$., hence, at lower temperatures we would expect larger flies with more chaetæ. Observations by Rasmuson (1952), Thoday (1958), Beardmore (1960) and Plunkett (1926) show that more chaetæ are present at lower temperatures, and a small trial at about $\mathrm{i} 7^{\circ} \mathrm{C}$. recently carried out (table 10) confirmed that at lower temperatures an increase in fly weight was correlated with an increase in chaeta number and a longer emergence time (see also Gibson, Parsons and Spickett, I961). Plunkett (1926) found that the chaeta number of flies was decreased progressively by growing larvæ for increasing periods at a high temperature after transferring from a lower temperature. Hence, no specific time during larval development is involved. We are dealing with a continuous process whereby fly size and chaeta number depend on the time of exposure to various temperatures. Auerbach (1936) showed that the two sterno-pleural discs separate during embryonic development; consequently the size of the discs will be affected by larval size, so influencing the size of the sterno-pleural plate and chaeta number.

On these arguments, in a line selected for high chaeta number, flies would be larger, and perhaps take longer to develop. It seems 
reasonable that as selection proceeds interactions would occur, and the regression of chaeta number on fly size would become non-linear, such that chaeta number would increase relatively more than fly size since chaeta number is being selected directly. Preliminary results confirming this (Gibson, Parsons and Spickett, I96I) indicate that fly size as measured by weight and by the surface area of the sterno-pleural plate, is increased after selection for sterno-pleural chaeta number; but the increase in fly size is less than would be expected on the basis of the regressions presented in this paper. It seems worth while recording fly size and development time as concomitant observations during the progress of an experiment in which chaeta number is being selected. Non-linearity would be expected in the phenomenon of accelerated response to selection (Sismanidis, I942; Mather and Harrison, I949;

TABLE II

\begin{tabular}{|c|c|c|c|c|}
\hline & \multicolumn{2}{|c|}{++} & \multicolumn{2}{|c|}{$e^{n}+$} \\
\hline & Chaetæ & $\begin{array}{c}\text { Weight } \\
(\mathrm{mgm} . \times \mathrm{so0})\end{array}$ & Chaetæ & $\begin{array}{c}\text { Weight } \\
(\mathrm{mgm} \times \mathrm{loo})\end{array}$ \\
\hline $\begin{array}{l}\text { Control (25 larvæ } \\
\text { per replicate) }\end{array}$ & $18 \cdot 4^{2}$ & $82 \cdot 13$ & I 7.99 & $84 \cdot 88$ \\
\hline $\begin{array}{l}\text { O.I } 6 \text { per cent. P.T.C. } \\
\text { (roo larvæ per repli- } \\
\text { cate) }\end{array}$ & $15 \cdot 4 \mathrm{I}$ & $45 \cdot 95$ & $16 \cdot 17$ & $45 \cdot 43$ \\
\hline Per cent. reduction . & $16 \cdot 34$ & $44 \cdot 05$ & $10 \cdot 12$ & $46 \cdot 4^{8}$ \\
\hline
\end{tabular}

Thoday and Boam, I96I), since this is due to the occurrence of recombinants for high chaeta number between interacting polygenes. The recombinants are then favoured by selection, and so chaeta number would rise rapidly, whereas fly size would hardly be expected to be affected so radically.

\section{(ii) Choeto number and fly size}

Reeve (I960) reported that a reduction of 23 per cent. in thoracic area was accompanied by a reduction in sterno-pleural chaeta number of 18.5 per cent. in the mid-parent between two Pacific inbred lines and $\mathrm{r}_{3}$. I per cent. in the $\mathrm{F}_{1}$. Comparing ++ and $e^{\prime \prime}+$ we get, for example, the results shown in table I I.

Hence the per cent. weight reduction is greater than the per cent. chaeta reduction, and on the basis of Reeve's data, it is also greater than the surface area reduction, since about the same chaeta reduction ( $<20$ per cent.) is accompanied by about 45 per cent. weight reduction and 23 per cent. thoracic area reduction. In small flies, therefore, chaetæ are more crowded than in large flies, and this occurs for sternite chaetæ (Robertson and Reeve, I 954). It seems legitimate to conclude 
that chaeta number falls with decreasing surface area and volume but less rapidly than both.

Robertson and Reeve (I954) found that females had 20 per cent. more abdominal sternite chaetæ than males, and on the basis of the linear dimensions of the flies, they concluded that sternite chaeta density is the same in both sexes. The sex-difference for sterno-pleural chaetæ, however, appears to be less; the females having 5-Io per cent. more chaetæ than the males in the data presented in this paper. The presence of 3 macro-chaetæ on each side in most flies indicates a greater degree of differentiation in the sterno-pleural plate than in the sternites. The macro-chaetæ, although occasionally absent in smaller flies, vary less than the micro-chaetæ, perhaps because they are of greater adaptive significance. This may have the effect of making the sexdifference for sterno-pleural chaeta number less than for sternite chaeta number. In general, it may be expected that the more closely related to fitness a morphological structure is, the less variable it will be.

\section{SUMMARY}

I. Larvæ of three genotypes, ebony, wild-type and heterozygous ebony were grown on various concentrations of phenyl-thio-carbamide (P.T.C.) at two levels of competition, namely 25 and roo larvæ per replicate. In general, as P.T.C. concentration increased, fly size decreased, and fly size variability increased. Emergence time and its variability both increased with increasing P.T.C. concentration. Sterno-pleural chaeta number decreased, but its variability was unaffected, which suggested that P.T.C. did not affect the developmental stability of the components of the fly, but only the size of the fly, perhaps by an interference with hormone production.

2. At the high level of competition, flies were smaller, had fewer chaetæ, and took longer to emerge than at the low level, but fly weight variance and chaeta number variance were not affected, although emergence time variance increased, no doubt in response to the additional stress involved.

3. The linear regression of fly weight on chaeta number was significant for all genotypes, but the regression line for the heterozygotes was significantly less steep than for the homozygotes, perhaps due to better homeostasis of the heterozygotes. A sex difference in regression lines was found and is perhaps due to the greater variability of females with developing eggs.

4. As the flies became smaller, the chaetæ became more crowded, even though there was a reduction in chaeta number. The percentage reduction of weight was greater than the percentage surface area reduction which was greater than the percentage chaeta number reduction, when comparing different fly sizes.

5. Flies grown at $30^{\circ} \mathrm{C}$. were smaller, developed more rapidly, and had fewer chaetæ than those grown at $25^{\circ} \mathrm{C}$. Fly weight, and 
emergence time variability were not affected appreciably at $30^{\circ} \mathrm{C}$., but sterno-pleural chaeta variability and asymmetry were increased, suggesting that temperature is a more "general" stress than P.T.C. for it affects the developmental stability of the components of the fly. The temperature data also indicate that fly size is in general correlated with chaeta number and emergence time. Hence, if in a selection experiment, chaeta number is being selected, it is plausible that there may be a partially correlated response of emergence time and fly size.

\section{REFERENCES}

AUERBACH, c. 1936. The development of legs, wings and halteres in wild type and some mutant strains of Drosophila melanogaster. Trans. Roy. Soc. Edin., $58,787-815$.

BEARDMORE, J. A. 1960. Developmental stability in constant and fluctuating temperatures. Heredity, 14, 41 1-422.

GIBson, J. B., PARsons, P. A., AND SPICKetT, s. G. Ig6r. Correlations between chaeta number and fly size in Drosophila melanogaster. Heredity, $I 6,349-354$.

KROMAN, R. A., AND PARSONS, P. A. 1960 . The genetic basis of two melanin inhibitors in Drosophila melanogaster. Nature, $186,4 \mathrm{I} 1-412$.

MANN, M. G. 1923. The occurrence and hereditary behaviour of two new dominant mutations in an inbred strain of Drosophila melanogaster. Genetics, 8, 27-36.

MATHeR, K. 1953. Genetic control of stability in development. Heredity, 7, 297-336.

MATHER, K., AND harRison, B. J. 1949. The manifold effect of selection. Heredity, 3 , $1-52$ and $131-162$.

OHNISHI, E. 1954. Melanin formation in the mutant ebony of Drosophila melanogaster. Annot. Zool. Fapon., 27, 76-81.

PARsons, P. A., AND Kroman, R. A. 1960. Melanin inhibitors and the ebony locus in Drosophila melanogaster. Heredity, 15, 301-314.

PLUNKETT, C. R. 1926. The interaction of genetic and environmental factors in development. 7. Exp. Zool., 46, 181-245.

RASMUSON, м. 1952. Variation in bristle number of Drosophila melanogaster. Acta Zool., 33, 277-307.

REEVE, E. C. R. 1960. Some genetic tests on asymmetry of sterno-pleural chaeta number in Drosophila. Genet. Res., I, 15 I-1 72.

REEVE, E. G. R., AND ROBERTSON, F. W. 1954. Studies in quantitative inheritance. VI. Sternite chaeta number in Drosophila: a metameric quantitative character. Z. Vererbungslehre, 86, 269-288.

SISMANidis, A. 1942. Selection for an invariable character in Drosophila. 7. Genet., $44,204-215$.

TEBB, G., AND THODAY, J. M. 1954. Stability in development and relational balance of the X-chromosome in Drosophila. Nature, 174 , 1 rog.

THODAY, J. M. I955. Balance, heterozygosity and developmental stability. Cold Spr. Harbor Symp. Quant. Biol., 20, 318-326.

THodAy, J. M. 1958. Homeostasis in a selection experiment. Heredity, I2, 401-415. THODAy, J. M., AND BOAM, T. B. 1961. Regular responses to selection. I. Description of responses. Genet. Res., 2, 161-176.

WOLSKY, A., AND KAlicki, H. G. I959. Oxidative metabolism and puparium formation in the ebony mutant of Drosophila melanogaster. Nature, I83, I129-11 30. 